\title{
Internal Audit Effectiveness in the Indonesian Property Industry
}

\author{
Antonius TP Siahaan,
}

Rudy Tantono

\begin{abstract}
The main purpose of this study is to analyze on the determinants of internal audit effectiveness in the public listed company in Indonesia specifically Top Ten Property Company by BCI Asia. Questionnaire was using for collecting data and distributed to the internal auditor and manager that has been audited by internal audit. The result of the study is to show the positive relation effects of Organizational Independence (OI), Formal Mandate (FM), Unrestricted Access (UA), Sufficient Funding (SF), Competent Leadership (CL), Objective Staff (OS), Competent Staff (CS), Stakeholder Support (SS) and Professional Audit Standards (PAS) with the internal audit effectiveness on the public listed company in Indonesia. The regreesion result shows OI, UA, SF, CL, OS, CS and SS have contributed for the internal audit effectiveness in the public listed company significantly and positively. The remaining two variable; FM and PAS were positively related with the IAE but their contribution for the IAE were statistically not significant. All of these nine independent variable are making $64 \%$ of the contributions for internal audit effectiveness in the public listed company.
\end{abstract}

Keywords:

Internal Audit Effectiveness, Organizational Independence, Formal Mandate, Unrestricted Access, Sufficient Funding, Competent Leadership, Objectives Staff, Competent Staff, Stakeholders Support, Professional Audit Standards.

\section{INTRODUCTION}

The growth and development of property in Indonesia is expected to be increasing, it can be seen from the developer creating a superblock development. Superblock development means the developer develop the property in one area and at that area has Malls, Hospitals, Schools, University, Real Estate, etc. Nevertheless, the increased number will not be a good sign for those developer since there are problems existed. YLKI (Yayasan Lembaga Konsumen Indonesia) stated that there are so many complaints from the customer regarding property such as: the handover of the building unit and certificate delayed, quality, specification and design of the building layout different, maintenance fee, the land that are going to develop is still dispute, the list of services that are in the brochure does not correspond with the actual, and refund funds are not immediately resolved. (Bayu, 2015)

From the data given by the YLKI and there are so manya others cases that did not expose to the outsider regarding the property cases, the company should take an action to minimize the complaints and cases. To solve the problems, the company should conduct an Internal Audit function. Every public listed company in Indonesia, most of them already had Internal Audit Function, but in this study, it will be study further about the factors that affected the Internal Audit Effectiveness of the company, so the Internal Audit function can minimize the complaints and the cases. The factor that are going to use in this study or the independent variable is the factors that are already determine by IIA to make Internal Audit more effective such as Organizational Independence, Formal Mandate, Unrestricted Access, Sufficient Funding, Competent Leadership, Objectives Staff, Competent Staff, Stakeholders Support and Professional Audit Standards. 


\section{LITERATURE STUDY}

Internal auditing is an independent, objective assurance and consulting activity designed to add value and improve an organization's operations. It helps an organization accomplish its objectives by bringing a systematic, diciplined approach to evaluate and improve the effectiveness of risk management, control and governance processes. (Protiviti, 2009)

Types of audits performed by Internal Auditors (Hailemariam, 2014): operations audits, financial audits, compliance audits, information system audits, internal control reviews and investigate fraud.

Internal audit effectiveness is the degree (including quality) to which established objectives are achieved (IIA, 2010). Effectiveness is the achievement of internal auditing goals and objectives using the factor measures provided for determinng such factors (Dittenhofer, 2001). Internal Audit effectiveness is the extent to which an internal audit office meets its supposed objective or the extent to which it meets the intented outcome.

The update practice guide by IIA presented nine key elements needed to establish an effective public sector audit activity.

\section{II.1.1. Organizational Independence}

Organizational independence allows the audit activity to conduct work and be perceived to conduct work without interference by the entity under audit. The audit activity should have sufficient independence from those it is required to audit so that it can both conduct and be perceived to conduct its work without interference.

Shamsuddin and Bharathii (2014) state that the internal auditor effectiveness is very much affected by the independence of internal auditors. If the internal auditors were not independent, the report they produce will be biased which in turn is useless in improving the accountability and transparency of the public sector as a whole. The objective and independent report produced by the internal auditor is one of the main keys to prevent scandals and frauds happening in the public sector. In fact, this is the main reason the internal audit function is set up in the ministry the first place.

\section{II.1.2. Formal Mandate}

The audit activity's powers and duties should be established by the public sector's constitution, charter, or other basic legal document. Among other topics, this document would address procedures and requirements of reporting and the obligation of the audited entity to collaborate with the auditor.

Hailemariam, Shewamene (2014), it stated that the existence of approved internal audit charter in the public sector office contributes for the effectiveness of internal audit works by facilitating the activities of internal auditors and to make their purpose and authority in line with the standards for the professional practices formulated by the institute of internal auditors in accordance to the rules and regulations of the organization

\section{II.1.3. Unrestricted Access}

Audits should be conducted with complete and unrestricted access to employess, property, and records as appropriate for the performance of the audit activities. 


\section{II.1.4. Sufficient Funding}

The audit activity must have sufficient funding relative to the size of its audit responsibilities. This important element should not be left under the control of the organization being audited, because the budget impacts the audit activity's capacity to perform its responsibilities.

\section{II.1.5. Competent Leadership}

The head of the audit must be able to independently and effectively recruit, retain, and manage highly skilled staff without undue managerial or political influence. The leader should be knowledgeable of applicable audit standards, professionally qualified-preferably certified-and competent to oversee and manage an audit activity. Moreover, the CAE should be an articulate public spokesperson for the audit activity.

\section{II.1.6. Objectives Staff}

An audit activity's staff must be objective. Audit staff must have impartial attitudes and avoid any conflict of interest. Conflict of interest is a situation in which an internal auditor, who is in a position of trust, has a competing professional or personal interest. A conflict of interest may exist even if no unethical or inappropriate act results. Such a conflict can create an apperance of impropriety that can undermine confidence in the internal auditor, the internal audit activity and the profession. Moreover, a conflict of interest could impair an individual's ability to perform audit duties and responsibilities objectively.

\section{II.1.7. Competent Staff}

The audit activity needs a professional staff that collectively has the necessary qualifications and competencies to conduct the full range of audits required by the mandate. Auditors must comply with minimum education requirements established by their relevant professional organizations and standards.

Shamsuddin and Bharathii (2014), they use Comptency of Internal Auditors to describe the competent of the staff and the result is Competency is the ability of an individual to perform a job or task properly, being a set of defined knowledge, skills and behaviour. In order to achieve competency, various types of training and development should be provided to internal auditors. A competent internal auditor will have all the skill necessary to produce a good audit report.

In Baharud-din et all ( 2014) they use Auditors Competency to describe Competent of the staff. Competency can be relate to the ability of an individual to perform a job or task properly base on the educational level, professional experience and the effort of the staffs for continuing professional development. Auditors' competency determines the effective auditing in the organization. It contributes to the ability of the auditors to perform the systematic and discipline audit approach to improve the effectiveness of IA.

\section{II.1.8. Stakeholders Support}

The legitimacy of the audit activity and its mission should be understood and supported by a broad range of elected and appointed public sector officials, as well as by the media and involved citizens.

Audit activity and its mission should be supported by the stakeholders. According to Baharuddin et all (2014) it stated The support and commitment of management also have the certain impact to make sure IA is functioning effectively. The success of IA function will depend on 
the strength of management's support for the auditing process. They have to accept the fact that the IA process is just as critical and important activity as any other process within the organization. Some study found that without management approval, support, and encouragement, the IA audit process are likely to face failure and worse - time and money wasted.

\section{II.1.9 Professional Audit Standards}

Professional audit standards, such as the International Professional Practices Framework (IPPF) promulgated by The Institute of Internal Auditors, support the implementation of the previous elements and provide a framework to promote quality audit work that is systematic, objective and based on evidence. Audit activities should conduct their work in accordance with recognized standards.

\section{METHODOLOGY}

The company's property that is selected for this research is a property company that included in BCI Top 10 Award Property Company in Indonesia. Data used in this study are primary data obtained through questionnaires. Questionnaires will be distributed to the auditor and manager that had been audited by internal audit of the compant. Total population is 200 respondent and the minimal sample data is 67 samples according to the Slovin sample size formula (Sevilla \& et.al, 2007). The questionnaire will be use a Likert-Scale with 4 categories which is there was no neutral categories.

Below is the model of analysis of the study, where is Internal Audit effectiveness is dependent variable and the independent variable is organizational independence, formal mandate, unrestricted access, sufficient funding, competent leadership, objectives staff, competent staff, stakeholders support and professional audit standards. 


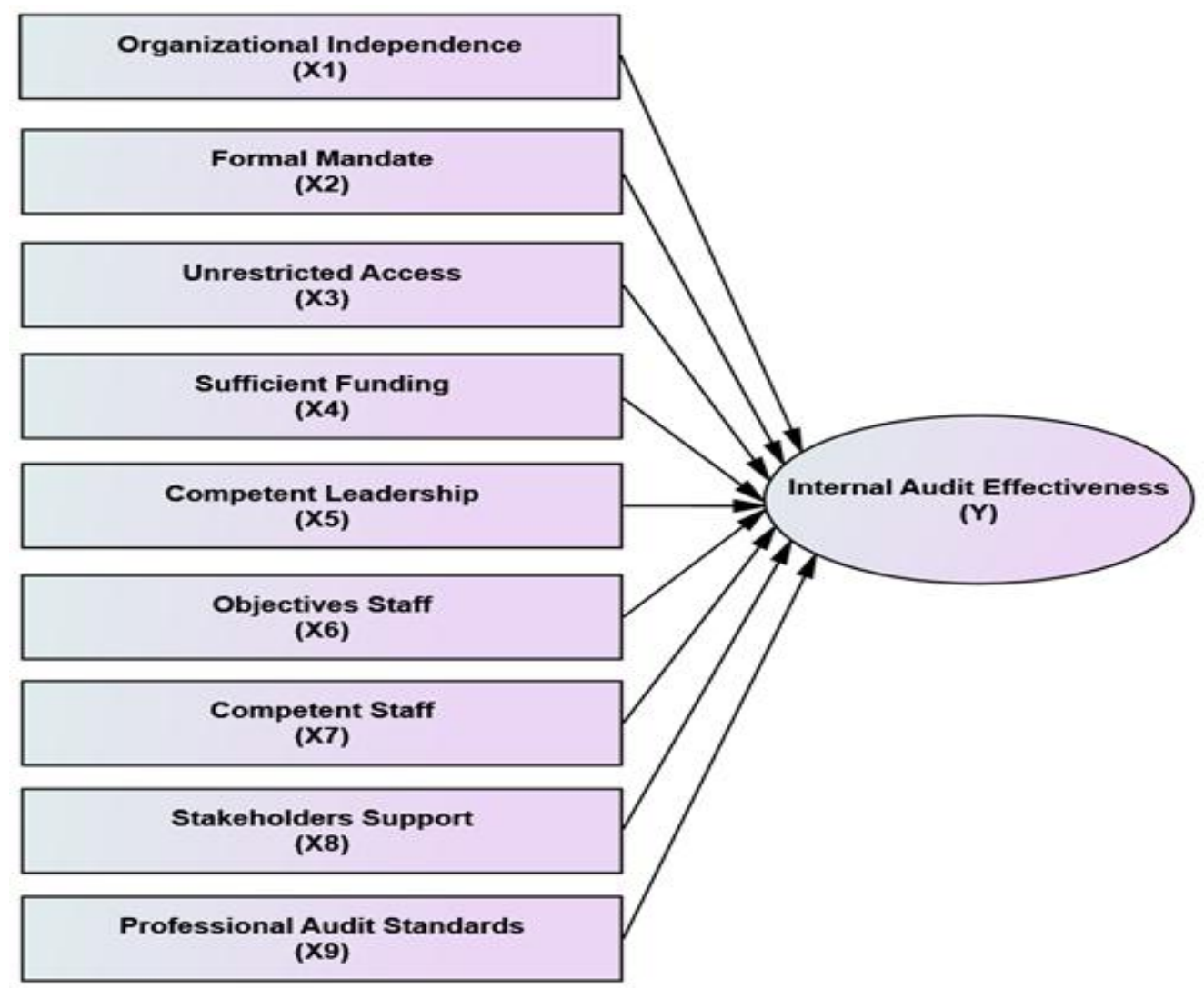

\section{RESULTS AND DISCUSSIONS}

The result of the validity and reliability test analysis, it shows that there are several question in the questionnaires should be removed or take out. The validity of the questions in the questionnaire show from the correlation coefficient where if the correlation coefficient greater than 0.444 with $n=20$ then the question is valid and if lower that 0.444 with $n=20$ then the question is not valid and must be eliminated or removed. Organizational Independence must remove 2 questions, Formal Mandate 1 question, Competent Leadership 1 question, Competent Staff 1 question, Stakeholders Support 1 question and Internal Audit Effectiveness 1 question. And for the reliability, it shows from the Cronbach's Alpha, if the Cronbach's Alpha greater than 0.6 then the variable is valid. In this study, all variable is reliable because the result of Cronbach's Alpha is greater than 0.6.

The result of the post test, the respondent for the managers $58(83 \%)$ were males and $12(17 \%)$ were females, while from the internal audit almost is the same with the respondent of the managers where $56(80 \%)$ were males and $14(20 \%)$ were females. The majority of the ages of the managers are falls under the age of 30-39 (64\%), 40-49 (21\%), 50-59 (11\%) and then 20$29(3 \%)$ and for the internal auditors are falls under the age of $20-29(47 \%), 30-39(31 \%), 40-$ $49(19 \%)$ and then $50-59(3 \%)$. In the term of field of study, the majority of managers and internal auditors were studied accounting 51\% (Managers) and 80\% (Internal Auditor) and the rest is Management 26\% (Managers) and 10\% (Internal Auditor) and Others 23\% (Managers) and $10 \%$ (Internal Auditor), but unfortunately there were no respondent who are study economics.

In the term of educational background, all of the managers and internal audit already got their Bachelor's Degree. No one of the managers and internal auditors are diploma background. Bachelor's degree 70\% (Managers) and 84\% (Internal Auditors) and Master's degree 30\% (Managers) and 16\% (Internal Auditors). 
There several questions that have to be answered by internal auditors, who are the main participants in the internal audit effectiveness, and the questions regarding the professional certification, experiences working as Internal Auditor and in their company has the audit committee or not. In term of professional certification, as it shows in the table above only 25 out of 70 internal auditor have a certification and other 45 did not have any certification.

In term of experiences working as Internal Auditor fell under the age of 5 to 10 years $(46 \%)$, below five years (37\%) and the last is 11 to 15 years (17\%). From the table, it shows there was no one that the experience working as internal audit more than 16 years.

In term of the presence of audit committee, all of the answer by the Internal Auditor is $100 \%$ has audit committee in their company.

This research finds the composite measure of Organizational Independence, Formal Mandate, Unrestricted Access, Sufficient Funding, Competent Leadership, Objective Staff, Competent Staff, Stakeholder Support and Professional Audit Standards amounted for 64\% $\left(\mathrm{R}^{2}=0.642\right)$ variance for the Internal Audit Effectiveness in identifying the non-compliance activities and internal auditor added value to the company. That means, the impact of nine independent variable contributed for the dependent variable Internal Audit Effectiveness were 64\% and the remaining $36 \%$ were other variables that are not included in this research.

Independent variable that give the most influence to the internal audit effectiveness is Competent Leadership where the regression result, B coefficients, amounted 0.155 and the followed by Organizational Independence with B Coefficient 0.152 and the next is Competent Staff with B Coefficient 0.123 , it means that if the company put a concern in increasing these three variables then the effectiveness of internal audit will be increase too.

There are four other variables that give influence to the internal audit effectiveness but not as big as the above variables such as Stakeholders Support with B Coefficient 0.12, Unrestricted Access with B Coefficient 0.12, Objectives Staff with B Coefficient 0.093 and Sufficient Funding with B Coefficient 0.075 .

And for the last two variables, Formal Mandate and Professional Audit Standards, eventhough these two variable has B coefficient amounted 0.061 and 0.069 , it will not give any influence or affect to the internal audit effectiveness because these two variable are not significantly affect the internal audit effectiveness, it means that if the company increase the Formal Mandate and Professional Audit Standards then the internal audit effectivenss in the company will not become more effective or less effective.

\section{CONCLUSION}

The correlation analysis shows all the independent variable have a positive correlation towards the Internal Audit Effectiveness in public listed company in Indonesia especially in property company. However, the statistical significance shows that there were two independent variable (Formal Mandate and Professional Audit Standards) insignificantly contributed to Internal Audit Effectiveness in public listed company in Indonesia especially in property company due to larger of significance level $p>0.05$, therefore this conclusions requires future research should be considered for obtaining the impact of these variables on the Internal Audit Effectiveness.

The finding of the research proved that the Organizational Independence, Unrestricted Access, Sufficient Funding, Competent Leadership, Objective Staff, Competent Staff and Stakeholders Supports were statistically significant and have a positive contributed to Internal Audit Effectiveness in public listed company in Indonesia especially in property company. Thus, the 
public listed company in Indonesia if they want their internal audit become more effective then the company should make the internal audit function become organizational independence, give the unrestricted access to all document, planning, forecast and data that support audit activities, give sufficient funding and compensation to do audit activities, have a competent leadership and staff and give full support to the Internal Audit Function so that they can be become more effective and the Internal Audit can be in line with IIA standards and the office policies and guidelines.

The internal auditors of the public listed company in Indonesia especially property company should be recommended to maintain and improve their effective contribution for the Internal Audit Effectiveness in their companies, by taking professional development activities to know more about Internal Audit Function, using the management or stakeholders support appropriately, do not do the audit activities subjectively and with conflict of interest, and the last is improving their professional certification in line with IIA Standards or Otoritas Jasa Keuangan standards and organizational guidelines and by introducing themselves with modern technologies that can improve their Internal Audit Function in the companies.

The last one is, the Indonesia higher educational institution should be contributed for the effectiveness of internal audit in public listed company in Indonesia especially in property company with supplying the competent staff and also give briefing how to hiring internal audit staff and also give appropriate training to upgrade the exisiting Internal Audit staffs profiency in line with the Institute of Internal Audit standards, or in Indonesia, can use Otoritas Jasa Keuangan standardization. 
Ahmad, N., Othman, R., \& Jusoff, K. (2009). The effectiveness of internal audit in Malaysian public sector. Journal of Modern Accounting and Auditing, 9(5), 784-790.

Al-Khaddash, H., Al-Nawas, R., \& Ramadan, A. (2013, September). Factors affecting the quality of Auditing: The Case of Jordanian Commercial Banks. International Journal of Business and Social Science, 4(11), 206-222.

Al-Twaijry, A. A., Brierley, J. A., \& Gwilliam, D. R. (2003). The development of internal audit in Saudi Arabia: An Institutional Theory Perspective. Critical Perspective on Accounting(14), 507-531.

Ankit. (2012, October 27). The Marketing Universe. Retrieved July 13, 2016, from The 4 point Likert Scale: http://ankitmarketing.blogspot.co.id/2012/10/the-4-point-likertscale.html

Arena, M., \& Azzone, G. (2009). Identifying organizational drivers of internal audit effectiveness. International Journal of Auditing(13), 43-60.

ASQ. (2013). ASQ. Retrieved from What Is Auditing: http://asq.org/learn-aboutquality/auditing/

Badara, M. S., \& Saidin, S. Z. (2013, July). The Journey so far on Internal Audit Effectiveness: a Calling for Expansion. Internaltional Journal of Academic Research in Accounting, Finance and Management Sciences, 3(3), 340-351.

Badara, M. S., \& Saidin, S. Z. (2013, July). The Relationship between Audit Experience and Internal Audit Effectiveness in the Public Sector Organizations. International Journal of Academic Research in Accounting, Finance and Management Sciences, 3(3), 329339.

Baharud-din, Z., Shokiyah, A., \& Ibrahim, M. S. (2014). Factors that Contribute to the Effectiveness of Internal Audit in Public Sector. 70(24), 126-132.

Balvanes, M., \& Caputi, P. (2001). Introduction to Quantitative Research Methods, an investigate approach. London, Thousand Oaks and New Delhi: Sage Publications.

BAPEPAM. (2008, November 28). Patent No. KEP-496/BL/2008. Indonesia.

Bayu, D. J. (2015, February 12). Kompas.com. Retrieved July 10, 2016, from Perhatian Buat Pengembang, 17 Keluhan Sering Diadukan Konsumen: http://properti.kompas.com/read/2015/02/12/190000321/Perhatian.Buat.Pengembang. 17.Keluhan.Sering.Diadukan.Konsumen

Bertram, D. (n.d.). Likert Scales.

botaavram, c., \& palfi, c. (2010). Methods of Measuring the Performance of Internal Audit. 10, 137-146.

Cassandra, S. L., Yee, A. S., Kieran, J., \& Jenny, K. S. (2008). Perceptions of Singaporean internal audit customers regarding the role and effectiveness of internal audit. Asian Journal of Business and Accounting, 1(2), 147-174. 
Chartered Institute of Internal Auditors. (2015). Chartered Institute of Internal Auditors. Retrieved June 10, 2016, from The difference between internal and external audit: https://www.iia.org.uk/about-us/what-is-internal-audit/

Cristina, A. B., \& Cristina, P. (n.d.). Measuring and Assessment of Internal Audit Effectiveness. 784-790.

Dittenhofer, M. (2001). Internal auditing effectiveness: An expansion of present methods. Managerial Auditing Journal, 1(2), 443-450.

Endaya, K. A., \& Hanefah, M. M. (2013). Internal Audit Effectiveness: An Approach Proposition to Develop the Theoretical Framework. Research Journal of Finance and Accounting, 4(10), 92-102.

Endaya, K. A., \& Hanefah, M. M. (2013). Internal Audit Effectiveness: An Approach to Develop the Theoretical Framework. Research Journal of Finance and Accounting, 10, 92-102.

Enofe, O. A., Mgbame, C. J., Osa-Erhabor, V. E., \& Ehiorobo, A. J. (2013). The Role of Internal Audit in Effective Management in Public Sector. Research Journal of Finance and Accounting, 4(6), 162-168.

Feizizadeh, A. (2012, May). Strengthening Internal Audit Effectiveness. Indian Journal of Science and Technology, 5(5), 2777-2778.

George, D., Theofanis, K., \& Konstantinos, A. (2015, July). Factors associated with Internal Audit Effectiveness: Evidence from Greece. Journal of Accounting and Taxation, 7(7), 113-122.

Hailemariam, S. (2014, June). Determinants of Internal Audit Effectiveness in the Public Sector, Case Study in Selected Ethiopian Public Sector Offices.

Hidayat, A. (2013, January 23). Statistikian.com. Retrieved June 25, 2016, from Uji F dan Uji T: http://www.statistikian.com/2013/01/uji-f-dan-uji-t.html

IIA. (2010). Measuring internal audit effectiveness and efficiency.IPPF-Practice Guide. The Institute of Internal Auditors.

IIA. (2012, Oktober). Altamonte Springs.

Jung, H. H., \& Lin, H. H. (n.d.). An Empirical Study on Effectiveness of Internal Auditing for Listed Firms in Taiwan. 1-21.

MacRae, E. L., \& Gils, D. V. (2014). Nine Elements Required for Internal Audit Effectiveness in the Public Sector. 1-44.

Mihret, D. G., \& Yismaw, A. W. (2007). Internal Audit Effectiveness: an Ethiopian Public Sector Case Study. Managerial Auditing Journal, 470-484.

MOFED (2004), Internal Audit Standards and Code of Ethics for Internal Auditors and Internal Audit Procedural Manual: Ministry of Finance and Economic Development 
NYSE. (2016). NYSE. Retrieved May 25, 2016, from Section 3 Corporate Responsibility: http://nysemanual.nyse.com/LCMTools/PlatformViewer.asp?selectednode=chp_1_4_ 3_1\&manual $=\% 2 \mathrm{Flcm} \% 2 \mathrm{Fsections} \% 2 \mathrm{Flcm}$-sections $\% 2 \mathrm{~F}$

Protiviti. (2009). Guide to Internal Audit (Second ed.).

Ruiqi, A. (2009). Using SERVQUAL . Journal of Service Research, 9(1), 87 - 107.

Russell, J. P. (2013). ASQ. Retrieved June 12, 2016, from What is Auditing?: http://asq.org/learn-about-quality/auditing/

Sakour, A. S., \& Laila, N. B. (2015). Internal Audit Effectiveness in Libyan Public Enterprises: An Approach to the Development of a Theoretical Framework. Global Business and Management Research: An International Journal, 7(2), 12-18.

Sekaran, U., \& Bougie, R. (2013). Research Methods for Business: A Skill Building Approach (6th ed.).

Sevilla, C. G., \& et.al. (2007). Research Methods. Quezon City.

Shamsuddin, A., \& Bharathii, D. (2014, Dec). Factors that determine the effectiveness of internal audit functions in the Malaysian Public Sectors. International Journal of Business, Economics and Law, 5(1), 9-17. 